\title{
A Sketch of the Controversy de auxiliis
}

\author{
R. J. Matava
}

Notre Dame Graduate School of Christendom College, Alexandria, VA, USA rmatava@christendom.edu

\begin{abstract}
In the 16th century, the Dominicans and the Jesuits engaged in a polarized theological debate about how God can move the human will in a way that neither compromises human free choice nor makes God the author of moral evil. This debate, called the "controversy de auxiliis," was never resolved. In 1607, Pope Paul v decreed that neither side was heretical and forbade further publishing on the issue without his explicit permission. This article explains the main theological points of the various Dominican and Jesuit actors, the human factors that contributed to the debate, and the reasons why this is still an important issue today. It concludes that both positions were based on important theological insights that would need to be taken into account if any resolution were to be found, that a resolution of this debate would benefit the Church in a number of ways, and that Jesuit and Dominican tribalism and polemics have contributed to keeping this issue unresolved.
\end{abstract}

\section{Keywords}

de auxiliis - nature/grace - Jesuits - Dominicans - Augustine - Thomism - Domingo Báñez - Luis de Molina - Francisco Suárez

Among the theological debates that have divided the Dominicans and Jesuits, the most infamous, fundamental, and enduring is the Controversy de auxiliis.

The controversy de auxiliis concerned the relationship between divine and human agency. More specifically, theologians disagreed over how to conceptualize the efficacy of "actual" grace (called auxilium or "divine assistance"). Was the efficacy of actual grace intrinsic and infallible, or determined by the human recipient? The division of actual grace into "operating" and "cooperating," anticipated by Augustine of Hippo (354-430) in the fifth century, was given 
lapidary expression by Thomas Aquinas (1225-74) in the thirteenth and was taken for granted by theologians of the sixteenth century. While the Dominicans and Jesuits of Scholasticism's silver age were concerned with divine/ human "cooperation" broadly conceived, their attention did not center on cooperative grace as such. Rather, they were especially concerned with seeking to understand the efficacy of God's operative actual grace.

The controversy de auxiliis occurred in the immediate wake of the Council of Trent (1545-63) and its protagonists probed questions about grace and conversion that Trent left unanswered. Moreover, the Society of Jesus was still a young religious order at the time of the controversy. Starting in 1582, the controversy de auxiliis began forty-two years after Ignatius of Loyola (c.1491-1556) founded the Society and twenty-four years after the Constitutions of the order were approved (1558). Similarly to the Dominicans, intellectual life was central to the Jesuit charism, and in the Society's Constitutions, Loyola even mandated that it would be the "scholastic doctrine of St. Thomas Aquinas" - a Dominican - which was to be taught in Jesuit schools. ${ }^{1}$ However, the Society of Jesus was not only a new order, but a new kind of order, one with a novel idea of the relationship between prayer and theological work, a different attitude toward the appropriation of Aquinas's thought, and a unique vision of how to live consecrated life. ${ }^{2}$ Consequently, the overlap of interests that might have united the Dominicans and Jesuits more closely in the apostolate also contributed to a rivalry almost since the latter order's inception. The controversy de auxiliis flowed from and contributed to this rivalry. While the controversy was officially terminated by Pope Paul v (1550-1621) after a quarter century in 1607, tensions between the two orders, especially on questions of grace, continued to simmer through the twentieth century, and remain, to some extent, even today.

My aim in this essay is to introduce the main contours of the controversy de auxiliis from an historico-theological perspective. Given the unifying aim of the collection of essays to which this piece contributes, I shall focus specifically on the principal Dominican and Jesuit positions in the controversy, although there were other positions worthy of consideration besides these. While my principal aim is historical rather than analytic or constructive, the

1 The Constitutions of the Society of Jesus and Their Complementary Norms: A Complete English Translation of the Official Latin Texts (St. Louis, MO: Institute of Jesuit Sources, 1996), IV.14, 464 (184).

2 For an insightful overview of some of these differences, particularly as they affected the thought of Luis de Molina, see Romanus Cessario, O.P., "Molina and Aquinas," in A Companion to Luis de Molina, Matthias Kaufmann and Alexander Aichele, eds., Brill's Companions to the Christian Tradition, 50 (Leiden: Brill, 2014), 291-323. 
thesis that I will propose in conclusion is that both the Dominican and the Jesuit positions in the controversy are erroneous, that common presuppositions led both sides into an insoluble dilemma, and that both sides nevertheless grasped certain relevant truths, not least, the deficiencies of the opposing point of view. Consequently, while the controversy failed to achieve resolution, it remains an instructive, not a fruitless debate. ${ }^{3}$

This essay is divided into four parts and a conclusion. The first part sets the controversy within its Augustinian context. The second part outlines the historical contours of the controversy. The third part summarizes the Jesuit position, concluding with a survey of the principal criticisms leveled against it. The fourth part summarizes the Dominican position, concluding with a survey of the principal criticisms leveled against it. Finally, the article concludes with some observations about the underlying causes of the disagreement.

Augustine's Legacy

In Augustine's Letter to Simplician, written many years prior to the Pelagian controversy, one detects an evident shift in Augustine's teaching on the relationship of grace and human free choice. Whether the shift one finds is a reversal of position or merely a change of emphasis is a matter of considerable debate. ${ }^{4}$ What is beyond question is the apparent diachronic tension in Augustine's thought between his anti-Manichean On Free Choice of the Will (c.388) and his later anti-Pelagian works, such as On Grace and Free Choice and On Rebuke and Grace (c.426-27). ${ }^{5}$ Augustine's mature position, the one that he

3 For a more detailed presentation of the controversy de auxiliis, including a constructive proposal, see my earlier work, Divine Causality and Human Free Choice: Domingo Báñez, Physical Premotion and the Controversy de auxiliis Revisited, Brill's Studies in Intellectual History, 252, ed. Han van Ruler (Leiden: Brill, 2016). The present essay is based primarily upon research undertaken for that book and I am grateful to the editors at Brill for publishing it.

4 In contrast to the view taken here, Gerald Bonner argues for a shift in Augustine's thinking, albeit a gradual one that had developed progressively over time. Bonner characterizes Augustine's position in the Letter to Simplician as expressing a "conversion," an "intellectual illumination comparable though not identical to the one that experienced at Milan in 386." See Gerald Bonner, Freedom and Necessity: St. Augustine's Teaching on Divine Power and Human Freedom (Washington, DC: cUA Press, 2006), 42. See also Gaetano Lettieri, L'altro Agostino: Ermeneutica e retorica della grazia dalla crisi alla metamorfosi del De doctrina christiana (Morcelliana: Brescia, 2001).

5 Augustine's On Free Choice of the Will, trans. Thomas Williams (Indianapolis: Hackett, 1993), comprises three books written across the period $c .388-95$. Augustine's affirmations of free choice in bk. 1 date from the earliest part of this period. 
maintains in the Pelagian controversy, takes shape in the Letter to Simplician, even though that letter predates Augustine's battle with the Pelagians.

Around 396, the elderly presbyter Simplician-Ambrose's friend, advisor, and successor to-be-wrote to Augustine with a set of thorny questions on the proper exegesis of St. Paul's Epistle to the Romans, particularly Paul's teaching on the value of the Old Law and on predestination. In the Letter to Simplician, Augustine agonizes over a pair of related tensions between two sides of the biblical mystery he is contemplating. ${ }^{6}$ The poles of that couplet of related tensions are these: that God wills the salvation of all, and yet some are lost; and that, on the one hand, man freely determines himself in respect to God's law and saving help, and on the other hand, that God alone has the initiative in salvation and exercises providential dominion over every human free choice.

Augustine resolves certain aspects of the tension found in Scripture and at points, his resolution can be judged inadequate by the standards of later Catholic thought and teaching. For example, in recognizing the effects of the fall as well as the necessity and prevenience of grace, Augustine taught that man can do no good apart from grace and that the universality of God's salvific will consisted only in God's intention to save individuals from every walk of life, not every human person. ${ }^{7}$ In these ways, Augustine's thought anticipated later "Augustinian" ideas, such as total depravity and limited atonement.

However, one finds in Augustine's thought an apparent tension that he does not resolve. This tension is not only diachronically apparent, but is also evident synchronically, within the Letter to Simplician itself. For example, Augustine's emphasis in the Letter on the prevenience and efficacy of grace does not contradict his affirmation of human free choice under the influence of grace, even if he does not explain precisely how the efficacy of grace coexists with the human person's freedom in choosing. The temptation is to read on to Augustine's thought a resolution that Augustine himself does not provide, and to miss the fact that what accounts for the tension is not only Augustine's having lived during a primitive stage of the church's theological reflection, but also his profound insight into Scripture's message about the transcendence of God and the mystery of creation.

Augustine's silence paved the way for later thinkers who, wishing to do justice to aspects of the biblical mystery that evidently were marginalized by

6 See especially Augustine, To Simplician, trans. John H. S. Burleigh, in Augustine: Earlier Writings, Library of Christian Classics, 4 (Philadelphia: Westminster Press, 1953), II.10-15 (393-97).

7 The church follows Thomas Aquinas in rejecting the view that the fallen person is incapable of any good act without grace. See ST I-II q. 109 (esp. a. 2); cf. Trent, Canons on Justification (1547): DS 1557 . 
his teaching, came into conflict with others who, wishing to adhere to Augustine's authority, amplified and focalized features of his anti-Pelagian thought that they took to be thematic and universal rather than nonessential results of the historical circumstances under which Augustine formulated his ideas. At the basis of later debates about predestination, justification, and the effects of the fall, for example, was a question about how man remains free as a selfdetermining agent under the influence of God's grace. This question Augustine did not answer, and his silence opened the space within which much would later be said.

The question of predestination occupied the minds of the later medieval theologians. Nominalist views on human free choice and its postlapsarian capabilities influenced positions on grace and predestination that were at odds with medieval receptions of Augustine such as those found in Aquinas and Scotus. Such divergences are also reflected in the different perspectives of such thinkers as Gabriel Biel (1425-95) and Johann von Staupitz (1460-1524), both of whom were influential on the development of Martin Luther's (1483-1546) thought, particularly his teaching on the bondage of the will. ${ }^{8}$ While the Council of Trent's teachings on human cooperation in justification and on merit are not preoccupied with human autonomy over and against divine sovereignty, the council fathers' affirmation of human free choice, in contrast to Luther and John Calvin's (1509-64) denials of it, can be understood as reflective of the same general division of thought discernable within earlier quarrels over grace, predestination, and freedom.

However, even the Council of Trent left unanswered certain pivotal questions about nature and grace, and the relationship between grace and human free choice. These questions came to the fore in the mid-sixteenth-century controversy at Leuven over the teachings of Michael Baius (1513-89). Baius advanced a kind of "conservative Augustinianism" that had affinities with the teachings of Luther and Calvin, while in different respects managing to come problematically close to the teachings of Pelagius. Baius, for example, taught that after the fall, man's nature was so wounded that free will was capable only of sin. Yet, he also maintained that man before the fall could merit eternal beatitude by his natural powers alone. Moreover, Baius reduced human freedom to mere freedom of external constraint - a freedom compatible with determinism of choice. Baius's influence reached such a point that in 1567 , Pope

8 See Leon Baudry, The Quarrel over Future Contingents (Louvain, 1465-1475): Unpublished Texts, trans. Rita Guerlac (Boston: Klewer, 1989). See also Heiko Oberman, Forerunners of the Reformation: The Shape of Late Medieval Thought Illustrated by Key Documents (Philadelphia: Fortress, 1981), 123-41. 
Pius v (1504-72) issued the bull, Ex omnibus afflictionibus, condemning around seventy-nine erroneous theses that were informally associated with Baius but not attributed to him by name. ${ }^{9}$ Due to Baius's recalcitrance and the lack of clarity in the pope's initial condemnation, Baianism remained an influential current at Leuven. The initial conflict with Baius stood as one bookend of the controversy de auxiliis and it also foreshadowed the second stage of that controversy, as described below.

Of all the debates over grace, predestination and freewill that ensued in the wake of Augustine's teaching, perhaps the most significant and intense was the controversy de auxiliis. This controversy may be summarized in four main periods or events.

The first milestone of the controversy was a theological debate at the University of Salamanca in 1582 between the Dominican Domingo Báñez (15281604) and the Jesuit Prudencio de Montemayor (d.1599). Convened by Báñez's Mercedarian colleague, Francisco Zumel (1540-1607), at the heart of this debate was the question of whether Jesus laid down his life freely, and therefore meritoriously, given that the Father decreed that he lay down his life. Montemayor argued that if the Father had decreed the laying down of Jesus's life, then Jesus would have died neither freely nor meritoriously, for Jesus would not have had any say in what came to pass. Báñez argued in reply that Montemayor's position contradicted Scripture and church teaching, in addition to being philosophically inadequate. The real point of concern was not Christological, but rather soteriological and anthropological: the question of Jesus's death provided a test case for sounding out positions on the efficacy of grace, and the relationship of human freedom and merit to divine foreknowledge and predestination. On Báñez's view, the Father predetermined Jesus to laying down his life, just as he predetermines all other creaturely free acts, whereas on Montemayor's view, the freedom of the human will excludes its predetermination by God. Consequently, for Báñez, grace is intrinsically and infallibly efficacious whereas for Montemayor, grace's efficacy is determined by the human person to whom grace is offered. While this initial debate did not end in the formal condemnation of either party, both accused each other of heresy and several of Montemayor's theses were submitted to the Spanish Inquisition for review.

9 DS 1901-80. 
The second milestone of the controversy was the quarrel at Leuven between the Flemish Jesuit Leonard Lessius (1554-1623) and the intractable disciples of Michael Baius, who, as described above, had been censured by the Holy See about twenty years earlier, but who meanwhile had been elevated to the influential rank of faculty dean at Leuven. Lessius's cause for concern was the Baianist faculty's teaching that God predetermines the will in the act of choice, that God sometimes demands the impossible, that not all receive grace sufficient for salvation, and finally, that predestination is ante praevisa merita (prior to foreseen merits) and not conditional upon foreseen merits (or post praevisa merita), as Lessius himself taught. The quarrel between Lessius and the Baianists became so heated that the matter was eventually referred to the Holy See for adjudication, though not before it reached the point of provoking fistfights in the streets of Leuven between students loyal to one side or the other. ${ }^{10}$ Ultimately, Pope Sixtus V (1521-90) called an end to the Leuven conflict without deciding in favor of either position, thus foreshadowing how Pope Paul $\mathrm{v}$ would terminate the entire controversy nearly twenty years later.

The third milestone of the controversy, and perhaps the most significant, was the publication of the Jesuit Luis de Molina's (1535-1600) magnum opus at Lisbon in 1588, The Reconciliation of Free Choice with Gifts of Grace, Divine Foreknowledge, Providence, Predestination and Reprobation for Several Articles of the Prima Pars of St. Thomas Aquinas. ${ }^{11}$ The publication of the Concordia, as it was called, can be considered the historical axis on which the entire controversy turned. Essentially, an extended commentary on a few select articles of the Summa theologiae of Aquinas, Molina expounded his teaching on the reconciliation of human free choice with God's causality and foreknowledge by advancing a theory of middle knowledge. According to the theory of middle knowledge, God knows how each possible human person would hypothetically act under any set of circumstances in which he or she could possibly be placed. Creating in light of such knowledge, God is able to control outcomes without any intrinsic determinism of the human person's will. Such a view of divine foreknowledge thus allowed Molina to reconcile a strong "libertarian" notion of human freedom with a commitment to divine providence as infallible

\footnotetext{
10 See Ludwig von Pastor, The History of the Popes from the Close of the Middle Ages, vol. 21: Sixtus V (1585-159o), trans. Ralph Francis Kerr (St. Louis, MO: Herder, 1952), 189.

11 The title of Molina's work in Latin is "Concordia liberi arbitrii cum gratiae donis, divina praescientia, providentia, predestinatione, et reprobatione ad nunnullos primae partis Divi Thomae articulos." The critical edition of this work is Liberi arbitrii cum gratiae donis, divina praescientia, providentia, praedestinatione et reprobatione concordia: Editionem criticam, ed. Johannes Rabeneck, S.J. (Oña: Collegium Maximum Societatis Jesu; Madrid: Societas Editorialis “Sapientia," 1953). Citations below will be from the critical edition.
} 
and comprehensive of all creatures and creaturely states of affairs. The Concordia was censured immediately upon its appearance by Dominican theologians (principally Báñez) who suspected Molina of asserting several of the propositions for which Molina's Jesuit confrère, Montemayor, had earlier been disciplined following his 1582 debate with Báñez at Salamanca. Printing and distribution of Molina's book was even stopped until Molina had secured an endorsement from Cardinal Albert Austriaco (1559-1621), the grand inquisitor of Portugal. However, even after gaining the Grand Inquisitor's approbation, the Concordia remained at the center of controversy. Within a year, Molina's book was being investigated by the Spanish Inquisition, and a few years later, as tensions mounted, Molina denounced Báñez and Zumel to the Inquisition for alleging that both maintained Protestant views condemned by the Council of Trent.

The fourth milestone of the controversy de auxiliis is really a series of events. After mounting tensions between the Dominicans and Jesuits over the efficacy of God's grace, the voluminous writings that had resulted from the conflict were sent to Rome en masse and Pope Clement VIII (1536-1605) established a papal commission called the Congregatio de auxiliis to investigate the matter in order to make a recommendation for an official resolution by the Holy See. The congregatio subsequently met scores of times over the next decade, adopting different formats for its proceedings in an attempt to overcome the stalemate. ${ }^{12}$ Clement VIII, who was determined to see the condemnation of Molina's view, died before promulgating any such condemnation, just as the Jesuit Robert Bellarmine (1542-1621) had earlier predicted. Leo XI (1535-1605) was next elected on oath that he would quickly resolve the controversy if made pope. However, Leo XI died after a reign of only twenty-seven days - one of the shortest in the history of the church. Following Leo XI, Paul V was elected in 1605. The congregatio resumed its meetings in his presence, but it came to no resolution. Throughout all of this, Molina several times only narrowly escaped condemnation. Although the position of Báñez and the Dominicans was also scrutinized, it was never as much the center of attention or in as much danger of condemnation.

Finally, in a move of pastoral prudence recommended by Francis de Sales (1567-1622), Paul v called an official end to the controversy in September of 1607 by affirming the tenability of both positions and banning the publication

12 For a detailed account of the of these complex proceedings, see the seminal histories written (respectively) from the Dominican and Jesuit points of view by Serry and deMeyer: See Jacques-Hyacinthe Serry, O.P., Historia congregationum de auxiliis divinae gratiae (Antwerp, 1709); and Livinus de Meyer, Historia controversiarum de divinae gratiae auxiliis (Antwerp: Petrus Jacobs, 1705). 
of books on the topic without the explicit approval of the Holy See. ${ }^{13}$ Moreover, the disputants were to await a final resolution of the matter by the Holy See, which, more than four-hundred years later, has yet to come. It is true that Paul v's termination of the controversy was a kind of resolution, but it was a disciplinary, not a theological resolution. The failure to resolve the controversy de auxiliis theologically allowed for other challenges to the Catholic faith to ensue in its wake, chiefly Jansenism, which was a kind of resurgence of several Baianist ideas. In light of these facts, one can reasonably consider the question of divine/human cooperation to be one of the most foundational, and at the same time, contentious issues in Christian theology.

The position originated by Molina and subsequently developed and defended in partnership with other influential Jesuits, most notably Francisco Suárez (1548-1617) and Bellarmine, was an attempt to reconcile two seemingly disparate realities, namely, human freedom and divine sovereignty. Of these two, human freedom had conceptual priority. This way of approaching the mystery is distinctive of the Jesuit position, for it suggests a difference from the manner in which the Dominicans approached the mystery. Whereas Molina began from the side of the human person and operated on the assumption that there were two realities that required harmonization, the Dominicans operated on the assumption that there was no tension to be resolved, and beginning from God's side, proceeded to explain what it could only mean for man to be free.

The Molinist attempt to reconcile divine sovereignty with human freedom may be reduced to three essential principles: first, a strong "libertarian" idea of human freedom; second, an understanding of divine concurrence as nondeterminative of the human will; and third, a prevolitional "middle knowledge" of conditioned possibility on the part of God.

\subsection{Libertarian Freedom}

The conceptual starting point of Molina's Concordia is the idea that free choice is the capacity to act or not act, to do one thing or another, positis omnibus requisitis ad agendum - that is, "in the presence of all requisite conditions for acting." ${ }^{14}$ According to Molina, for a choice to be free, it must not be determined

\footnotetext{
13 According to the 1917 Code of Canon Law §6.6, this prohibition is not currently applicable.

14 Molina, Concordia, I d. 2 §3 (14).
} 
by any antecedent or set of antecedent conditions, not even divine action. This last qualification is a distinctive feature of the Jesuit view of freedom, and it differentiates the Jesuit view from that of the Dominicans.

Molina and the Jesuits believed such a view was the only way to account for the experience of making choices. They also believed that such a view was supported by Scripture. Moreover, they found support for their view in the church fathers, especially the Greek fathers, who had a strong notion of man's moral responsibility and never had to refine their teaching on freedom of the will in response to the challenge of Pelagianism. On the other hand, while certain aspects of Augustine's teaching presented foundational challenges to the Jesuits' view, other aspects of his teaching - especially his early work on free choicelent support to it. Perhaps the greatest overarching reason for the Jesuits' view of human freedom was the thought that moral responsibility could not be maintained without it. The affirmation of human moral responsibility was of crucial importance to the Jesuits for the same reason it was important to $\mathrm{Au}$ gustine: It allowed for a plausible explanation of the origin of evil in a universe created by a good, unitary and omnipotent God. In particular, the Jesuits were concerned in their teaching not to make God the author of sin or the first cause of a person's eternal perdition.

Such an explanation of freedom and responsibility was also integral to the Jesuits' spirituality — a spirituality shaped by the circumstances in which their order was founded. Central among these was the spread of Luther and Calvin's views of grace and sin, justification, merit and predestination, as well as the Catholic Church's response at the Council of Trent. Luther had famously denied free choice in his exchange with Erasmus (1466-1536) - an exchange which resulted in what many consider to be Luther's greatest work, De servo arbitrio - and Luther had even identified this denial of human freedom as the kingpin and foundation of his entire theology. ${ }^{15}$ Calvin followed Luther in suit, and Calvin took Luther's views on the bondage of the will to their logical conclusion in his doctrine of election and double predestination. It comes as no surprise then to find Loyola advising his readers in the Spiritual Exercises, "Nor should we talk so much about grace and with such insistence on it as to give rise to the poisonous view that destroys freedom [...] our language and way of speaking should not be such that the value of our activities and the reality of human freedom might be in any way impaired or disregarded, especially in

15 See Luther, De servo: Luther and Erasmus: Free Will and Salvation, trans., ed. E. Gordon Rupp and Philip S. Watson, Library of Christian Classics (Philadelphia: Westminster, 1969), 122, 128, 137-38, 333 . 
times like these which are full of dangers."16 Whereas the bondage of the human will may be considered the most foundational aspect of Luther's theology, in contrast, free choice of the human will may be considered the most foundational aspect of the Jesuits' theology.

\subsection{Non-Determining Divine Concurrence}

The Jesuits have a highly nuanced and affirmative account of God's causation of human free choices, called "concurrence." Concurrence is an influx of divine efficient causation. As the name itself suggests, concurrence is the confluence of divine action with, but not on the human agent. God concurs in the action of the human agent to bring about a certain effect, such that there is but one action and one effect, even though there are two agents. For the Jesuits, God's action and the human action are numerically the same action, an action which comprises two distinct, correlative streams of influence resulting in a single effect. Molina conceived of divine/human cooperation as the coordinated effort of two partial causes and famously illustrated this conception with the example of two men dragging a barge: each man is a cause in his own right and each makes his own distinct causal contribution such that their concomitant effort results in a single effect - an effect one man would be unable to produce without the contribution of the other agent. In the case of God and man, on Molina's account, God's role is to supply the esse to man's act of will, whereas man's role is to supply the determination that characterizes the choice as a choice of this. The human person thus acts as a particularizer of God's general causal influx. The human person cannot choose apart from God, for he or she is a creature dependent on the creator for being and action. But God does not supplant human agency in bestowing his concurrence, for that concurrence has to be channeled in a particular direction by the human agent. In this way, God does cause human free choices, but not in a way that determines them.

While agreeing fundamentally with Molina's account of concurrence, Suárez differs in point of detail by maintaining that God and the human person are not partial coordinated causes, but total causes, each complete within its own order for the production of the single, joint effect. On Suárez's understanding, God does not provide an indifferent, indeterminate esse, for the esse God gives to a particular act of choice has the determinacy settled by the

16 Ignatius of Loyola, "Rules for Thinking with the Church," appendix to the Spiritual Exercises, trans. Thomas Corbishley, S.J. (Wheathampstead: Anthony Clarke, 1973), 123 (no. $369 / 17)$. 
creaturely act he makes real. And the human act of self-determination that limits the esse provided by God has no reality - is no real determination at all—apart from God's existence-giving concurrence in that act. ${ }^{17}$ God always provides a particular esse for a particular choice. Still, for Suárez-like Molina and unlike their Dominican opponents-God's giving the esse to a choice is not what determines the choice. For Suárez, while God's concurrence is nondetermining, it is not therefore indeterminate.

According to the Jesuit view, the single cooperative action of God and the human person is the single, joint effect they bring about by their action. Therefore, the unity of effect explains the unity of the action of the two agents. The concurrence of $A$ in bringing about effect $E$ just is $E$ considered in relation to $A$-it is $E$ 's dependence upon $A$. Similarly, the concurrence of $B$ in bringing about effect $E$ just is $E$ 's dependence upon $B .{ }^{18}$ According to Suárez, the dependence of an effect on its cause is a mode of the effect, identical in reality with the effect, but nevertheless objectively (and more than just conceptually) distinct from it. ${ }^{19}$ Thus, God's concurrence is not antecedent to the action of the creature, whether in time or in the order of nature. Rather, God's concurrence is temporally simultaneous and naturally concomitant with the action of the created agent. Nevertheless, the coordinated action of God and the human person has a natural priority to the effect they jointly bring about. ${ }^{20}$ Suárez, for example, describes action as a "path" to the effect. ${ }^{21}$ This intuitive priority of action (in this case, a conjoint action) to effect is intelligible in light of the distinction, ex natura rei (due to the nature of the thing), of action from effect. This feature of the Jesuit position is important to notice because it reveals that while the Jesuits labor strenuously to avoid conceptualizing causality as a tertium quid between cause and effect, they ultimately fail to steer entirely clear of

17 Thus, Suárez does not easily fall prey to the charge that he hypostasizes and separates esse and essentia.

18 In Divine Causality and Human Free Choice, I imprecisely stated (314) that, for Suárez, action and dependence "are only formally distinct." Rather than bringing in the Scotist formal distinction, I should have indicated that for Suárez, action and dependence are conceptually distinct.

19 That is, an effect's dependence upon its cause is a mode of the effect that is distinct $e x$ natura rei from the effect. This sort of a distinction lies between a mere conceptual distinction and a real distinction. For details and references, see my earlier study, 311-12.

20 See my earlier study, 308-10.

21 See Suárez, $D M 18$ §10.6 (252); see also 20 §4.14 (74), 16-17 (76-77), 30 (88); 48§1.12. Parenthetical citations are to page numbers in Freddoso's translations: On Efficient Causality: Metaphysical Disputations 17, 18, and 19 (New Haven: Yale, 1994); and On Creation, Conservation and Concurrence: Metaphysical Disputations 20, 21, and 22 (South Bend, IN: St. Augustine's Press, 2002). 
intuition's siren song. Yet, as they themselves recognize, the notion that causation is a kind of bridging reality between cause and effect is one of the most decisive factors that leads to their opponents' theological determinism. ${ }^{22}$

\subsection{Middle Knowledge}

Middle knowledge is God's pre-volitional knowledge of how possible created persons would act under any given set of circumstances in which they could be placed. It is called "middle" because conceptually, it lies between God's prevolitional knowledge of his own nature and creative possibilities on the one hand, and God's postvolitional knowledge of the actual world on the other. God's prevolitional knowledge of his own nature and creative possibilities is called his "simple" knowledge, or scientia simplicis intelligentiae. ${ }^{23}$ It is called "prevolitional" because it is conceptually prior (from a human point of view) to God's free volition to create. God's simple knowledge is also necessary: God cannot fail to know his own essence and God's essence cannot not-be. Moreover, God knows all possibles in his simple knowledge because in knowing his own essence, he knows all to which his creative power could extend. In contrast, God's postvolitional knowledge of the actual world - called scientia visionis, or "knowledge of vision" - could be otherwise, because the actual world could be otherwise or not be at all. ${ }^{24}$ This is not to say that God's knowledge is mutable or fallible. It is simply to say that if the world were different, God's knowledge of it would be different. There is always an unchanging correspondence between God's intellect and any realities external to it (even if those realities are themselves contingent).

Whereas God knows everything that is absolutely possible in his simple knowledge, God by his middle knowledge knows what is "feasible."25 For on the Jesuit view, not everything that is absolutely possible is actually feasible for God. The reason for this is that creaturely freedom-understood as the capacity to do this or that, to act or not act, given all of the antecedents to choiceconditions God's creative possibilities. For example, if Jane, in a given set of circumstances, is free in respect to choosing to go to law school, then Jane,

22 By "theological determinism" I mean the idea that God determines the choices of the created agents he moves to the act of choice. Dominican proponents of theological determinism denied that human free choices were determined by any created causes other than the human agent.

23 See $S T$ i q. 14 a. 9.

24 See $S T$ I q. 14 a. 9.

25 I borrow this apposite distinction between what is possible and what is "feasible" from Thomas Flint, Divine Providence: The Molinist Account (Ithaca: Cornell University Press, 1998), 51-54. 
under those circumstances, can choose to go to law school or not. ${ }^{26}$ God, in his simple knowledge, knows both of these possibilities: that Jane, in the given circumstances, chooses law school, and that she, in those same circumstances, chooses not law school. However, whether or not Jane in the given circumstances would in fact choose law school is not up to God, but to Jane, because Jane is free in a libertarian sense. If Jane under the given circumstances would freely choose law school, God cannot make it to be the case that Jane, under the same circumstances, chooses not law school. He can, however, make it to be the case that Jane chooses not law school by placing Jane in different circumstances under which she would choose not law school. By creating in light of his middle knowledge, God maintains control over everything that happens in the actual world without causally determining everything that happens in the actual world. God never determines Jane's will, for there is merely a correlation between the antecedent circumstances and her choice. The antecedent circumstances are not a sufficient reason for Jane's choice, for Jane's choice is only counterfactually dependent, and not causally dependent, upon the antecedent circumstances. From this it is clear how middle knowledge is the kingpin of the Molinist theory, for it is what allows the Jesuits to hold together human freedom and divine sovereignty.

Molina does not endeavor to explain how God has middle knowledge. Rather, he appeals to divine incomprehensibility and believes simply that God has middle knowledge through his "supercomprehension" of creatures. For Molina, because God is omniscient, God's knowledge scrutinizes creaturely essences in such depth that he must know how any creature he could create would act under any set of circumstances in which it could be placed. Suárez goes further than Molina in this regard. According to Suárez, God's omniscience implies that he knows all truths. And on his view, the laws of logic imply that for every pair of contrary counterfactuals, one must be true and the other false. Therefore, God, by his middle knowledge, knows which of every pair of contrary counterfactuals is the true one. For Suárez, it is not just the power of the divine intellect that explains middle knowledge, it is also the inherent knowability of the objects of middle knowledge - a knowability implied by such basic principles of logic as the principle of bivalence and the law of excluded middle.

Thus, if prima facie, the theory of middle knowledge seems inflationary, it is important to realize what motivates the theory and the costs of denying it: Molina affirms middle knowledge because it appears to him to be the only way

26 By extension, in choosing not to go to law school, Jane might be free in respect to other options, such as pursuing a philosophy degree. 
of simultaneously accounting for core truths of faith, and the cost of denying middle knowledge is not only the rejection of certain essential truths of faith, but also, in Suárez's view, the rejection of foundational principles of logic.

\subsection{Congruism}

Congruism is a later development of the Molinist theory made possible by the pressure of controversy, which forced deeper reflection on and clarification of certain aspects of Molina's position. While there was unity in essentials across the Jesuit school, there were some important differences on two theological applications of the foundational principles of the Jesuit position. Those two theological applications concern the efficacy of grace and predestination. Recall that the question at the heart of the controversy de auxiliis was whether actual grace was intrinsically and infallibly efficacious, or whether its efficacy was determined extrinsically, by the human recipient. According to Molina and Lessius, the efficacy of efficacious grace is not intrinsic and infallible, for if it were, the human will, moved by such grace, would be determined by it and not free. Instead, for them, the efficacy of grace is determined by the free human response to accept or reject that grace. Likewise, Molina and Lessius maintained that predestination was not ante praevisa merita (before foreseen merits), but post praevisa merita (after foreseen merits), evidently making human merits the ultimate basis for divine election.

These aspects of the Jesuit position drew sharp criticism from the Dominicans, who questioned how the divine initiative in salvation-consistently affirmed by the church and recently re-articulated at the Council of Trentcould be maintained. They also pointed out how the position of Molina and Lessius on the conditional nature of predestination contradicted the view of Augustine and Aquinas. But some of Molina's ablest defenders, including Suárez and Bellarmine, thought a more conservative view possible. The differences between the two Jesuit positions are not fundamental. ${ }^{27}$

While congruism stood on the same three legs as unmodified Molinism, the congruists affirmed the antecedent and infallible efficacy of actual grace and maintained that predestination was ante praevisa merita. According to their view, God, by foreseeing in his middle knowledge how an individual would respond to particular graces that could be offered, chooses to give these graces under these circumstances, knowing that they will be efficacious for the

27 Henri Quillet (who is sympathetic to Molinism) argues that there is no essential difference between Molinism and congruism, maintaining that the differences there are theological, but not psychological. By this he means that there is a difference from the aspect of God's role, but not a difference from the aspect of human experience. See his "Congruisme," in Dictionnaire de théologie catholique (Paris: Letouzy et Ané, 1908), 3-1: 113ob ff. 
outcome God desires. In this way, it is possible to affirm the antecedent efficacy of the graces God gives: these graces under these circumstances just do bring about the divinely desired effect. This is why the graces in question are called "congruous": that is to say, they befit or are proportioned to the coming about of the particular effect that God wills to bring about, as Augustine describes in his Letter to Simplician. ${ }^{28}$ It is this congruity of a particular grace to a particular effect in a particular person that God foresees in his middle knowledge.

But while efficacious grace is antecedently and intrinsically efficacious on the congruist view, it is important to note that grace's efficacy hinges on the infallibility of God's middle knowledge rather than on the inherent properties of the grace. For it is not that an efficacious grace has the intrinsic power to determine the will of the recipient whereas a merely sufficient grace does not. The difference between efficacious and sufficient grace for the congruist is not intrinsic, but relative: the efficacy of grace is a function of the divinely known alignment of the grace with a person's moral individuality and external circumstances. This is how, for the congruists, the antecedent efficacy of efficacious grace is rooted in the infallibility of God's middle knowledge, rather than in the grace itself, as the Dominicans thought. Once this is realized, one can see that the proximity of congruism to the Dominican position and its distance from the Molinist position, while real, is superficial. The chief significance of the congruist modification of the Jesuit position is that, by paring the Jesuit position back to its essentials, it isolates the issues that genuinely divide the Jesuits from the Dominicans so that those issues can be dealt with openly and without distraction.

\subsection{Criticism of the Jesuit Position}

The three principles of the basic Jesuit position outlined above stand as three axes along which Dominican criticism of the Jesuit position can be analyzed. The most obvious common thread running throughout the Dominican critique is that the Jesuit position is at least dangerously close to Pelagianism, if not identical to it in essentials. ${ }^{29}$ But this perspective on the Jesuit doctrine of grace is a spillover of the more fundamental charge that the Jesuits misconceive the relationship between God and creatures on even the natural level. This misconstrual is most evident in the Jesuit notion of free choice, which seems to remove human self-determination from God's causal purview, making the human person a creator, ex nihilo, of his or her own choices.

28 See Augustine, To Simplician II.13 (395).

29 Note that even if their theory is ultimately flawed, the Jesuits explicitly disavow Pelagianism and the Magisterium has cleared them of the charge (see for example, DS 2564). 
One might reply to this charge with the Jesuit notion of concurrence, for that account is deployed precisely to account for how God causes the positive reality of human free choices. However, the Dominican critique goes through because according to the Jesuit account of concurrence, God works with and not on the human agent. Whence, therefore, arises the human agent's contribution? The human agent's causal contribution originates absolutely from the human agent, and moreover, it conditions God's causal possibilities, circumscribing the range of the possible to the more limited domain of what God can "feasibly" bring about. While the Jesuits maintain on the one hand that without God's concurrence there is no actual creaturely self-determination at all, their recourse to middle knowledge reveals that there is something positive at the core of the human act of free choice that is not caused by God, but which confronts God as an extrinsic given, prior to creation. Were that not so, middle knowledge would be superfluous.

To the extent that middle knowledge is symptomatic of an underlying error in the Jesuits' idea of human freedom and divine causality, error also creeps into the doctrine of middle knowledge itself, undermining its plausibility. That is because the putative objects of middle knowledge must have some reality, some determinacy, in order for there to be middle knowledge. But insofar as middle knowledge is prevolitional, there can quite literally be nothing extrinsic to God that conditions his knowledge, for God is the creator of all that is. This objection, called, in contemporary literature, the "grounding objection," is the most trenchant argument against middle knowledge.

But is the grounding objection sound? Defenders of the Jesuit view say it is not, appealing to the fact that the truth conditions for counterfactuals of creaturely freedom must respect the modality of counterfactuals in general. Appealing to the conditional nature of counterfactuals in general, defenders of the Jesuit view point out that because counterfactuals are not propositions about what is the case, but about what would be the case, we should not expect there to be any existing states of affairs that could serve as truth-makers for true counterfactuals. ${ }^{30}$ And it is plausible that there are some true counterfactuals.

However, while critics of the Jesuit view admit that there may be true counterfactuals of determined action - counterfactuals whose truth is grounded in existing states of affairs, such as the natural dispositions of things- they maintain that there are no true counterfactuals about free actions, since these actions, insofar as they are free, are not determinate through any convergence of

30 See for example, William Lane Craig, Divine Foreknowledge and Human Freedom: The Coherence of Theism; Omniscience (Leiden: Brill, 1991), 260-63; Flint, Divine Providence, 12176; and Trenton Merricks, Truth and Ontology (Oxford: Clarendon Press, 2007), 146-55. 
existing, antecedent conditions. This means that both members of a pair of contrary counterfactuals of freedom are, in fact, false. Contrary to Suárez's attempt to ground the truth of counterfactuals in the principle of bivalence and the law of excluded middle, the Dominican, Diego Álvarez (c.1550-1631), pointed out that contrary counterfactuals are not contradictories, such that one member of every pair would have to be true. ${ }^{31}$ The contradictory of a counterfactual is the negation of the entire counterfactual-inclusive of both the antecedent and the consequent - not just the negation of the consequent part of a counterfactual proposition. Therefore, contrary counterfactuals can both be false.

Last, one might attempt to shore up the truth of counterfactuals by appealing to the fact that the grounding objection comes at too high a cost, for it seems to entail the falsity of all future contingent propositions, not just counterfactual ones. That is because insofar as the future does not yet exist, there are also no future states of affairs to serve as truth-makers even for "factual" propositions about the future, and yet it seems that some propositions about the future are true. ${ }^{32}$ However, by asserting that no proposition about the future is determinately true or false until its truth conditions are fulfilled in the timeframe referenced by that proposition, one can deny the determinate truth of factual future contingents without sacrificing bivalence and excluded middle. Until the relevant future timeframe, contradictory propositions concerning what happens in that timeframe are either-true-or-false (there is no middle truth value between truth and falsity, so fuzzy logic is avoided), but prior to that relevant future timeframe, neither proposition is determinately true or determinately false. ${ }^{33}$

Ultimately, a defender of the Jesuit view might be tempted to respond to the objections outlined above by saying that they all (at least implicitly) suppose the falsity of libertarian freedom, that such a supposition begs the question, and that there are good independent reasons for affirming libertarian freedom. Perhaps, then, our certitude about libertarian freedom should cause us to rethink received notions of God. Whatever one makes of such a suggestion it is

31 See Diego Álvarez, O.P., De avxiliis divinae gratiae et humani arbitrii viribus, et libertate, ac legitima eivs cvm efficacia eorvndem avxililiorvm concordia liberi duodecim (Cologne: Antonius Boetzerus, 1622), II d. 7 §4 (63b), §30 (86a); d. 13 §1 (111b-112b). Concordia), trans. Alfred Freddoso (Ithaca: Cornell, 1988), 68-81.

33 See Harm J. M. J. Goris, Free Creatures of an Eternal God: Thomas Aquinas on God's Infallible Foreknowledge and Irresistible Will (Leuven: Peeters, 1996), 232-33. On this view, the truth of prophetic claims can be secured by the actuality of future states of affairs to the eternity (or to the decretal infallibility) of God who inspires the prophets. 
not a line of thought the early Jesuits were interested in pursuing, for they had no intention to depart from a traditional conception of the divine attributes (wherever their theory may in fact have led).

\section{4}

The Dominican View

In contrast to the Jesuits, the Dominicans' approach can be described as theocentric rather than anthropocentric. Starting from an assertion of God's universal causality and providence (factors that entail God's initiative in salvation), the Dominicans take for granted that these encompass human freedom. They do not assume that there is any problem or tension between divine sovereignty and human freedom that needs to be resolved. For the Dominicans, the truth about human freedom can only be discovered in light of foundational principles about God's nature and action. ${ }^{34} \mathrm{~A}$ commitment to these principles shapes and limits the Dominicans' account of human freedom.

A subordinate factor that shaped the Dominican position in the controversy de auxiliis is the influence of Aquinas and the commentarial tradition that propagated his influence. Thomas was one of the order's earliest members and a thinker whose significance by the time of the controversy had been universally recognized. Canonized two-and-a-half centuries earlier in 1323, Aquinas's Summa theologiae was privileged to be one of the three works placed on the altar in the hall of assembly during the Council of Trent along with Scripture and the papal decretals. Moreover, Thomas was named a Doctor of the Church by Pope Pius $v$ four years after the council, in $1567 \cdot^{35}$ This was in the same year that the theses of Michael Baius were condemned, and just prior to the outbreak of the controversy de auxiliis. While even the Jesuits were Thomists in the broad sense of the word (privileging his doctrine as that which would be taught in their schools) the Jesuits' appropriation of the Angelic Doctor's thought tended on the whole to be much freer and more eclectic than that of their Dominican counterparts, such as Báñez, who did not want any light to

34 The Dominicans do not approach divine causality and human freedom as opposing realities that need to be "reconciled" because if God really is the first principle, then all you have is God, and everything else in relation to him. God's causal action cannot rival human freedom because God's action is the only way anything gets off the ground-it is the only way you have anything at all (such as human freedom) to deal with. Apart from God, there simply are no created causes or creaturely operations. This reveals how firmly grounded in the doctrine of creation the Dominican position is.

On Aquinas's Summa at the Council of Trent, see Leo XII, Aeterni Patris 22. 
shine between his position and that of Thomas. ${ }^{36}$ Báñez, if outstanding, was not a unique case. All members of the Dominican order were obliged not only to study, but also to promote and defend the teaching of Aquinas. ${ }^{37}$ Furthermore, Romanus Cessario maintains that the Dominicans approached theological study differently than the Jesuits: whereas the Jesuits sharply distinguished contemplative prayer from study, the Dominicans laudably integrated them, approaching study as a way to enhance theological faith. ${ }^{38}$ However, this integral approach to study, combined with the obligation to propagate and defend Thomistic theology, led in practice to a blurring of the distinction between apostolic tradition and Scholastic tradition.

While Thomas did not follow Augustine's view that fallen man was incapable of any good without grace, it is Augustine, after Paul the Apostle (c.4-c.64), who most influenced Thomas's teaching on grace. While Thomas did not explicitly distinguish efficacious from sufficient grace as did his later commentators, he did explicitly teach that God acts in every acting creature and that God moves a person's free will in the act of choice. ${ }^{39}$ Thomas also held for the infallible efficacy of the divine will.

Starting from the conviction that God is the universal first cause, the Dominicans articulated an account of how God pre-moves or "predetermines" secondary causes to act-even free secondary causes. In this section, I will first outline the general features of the Dominican theory of premotion. Second, I will explain the ramifications this has for the Dominican position on predestination and the efficacy of grace. Third, I will turn to the Dominicans' understanding of free choice and how this fit within their general theory of premotion.

\subsection{Premotion}

The Dominicans understood God's application of secondary causes in light of the doctrine of creation and the Aristotelian teaching on potency and act. On

36 See John R. Volz, "Báñez, Domingo," in The Catholic Encyclopedia, ed. Charles G. Habermann et al. (New York: Robert Appleton, 1907), 2:248, who recounts that Báñez alleged he strove not to depart "so much as a fingernail's breadth, even in lesser things," from the thought of Aquinas.

37 See Cessario, "Molina and Aquinas," 302.

38 See Cessario, "Molina and Aquinas," 301-2.

39 See, for example, $S T$ I q. 105 a. 5; I-II q. 9 a. 4, 6; q. 10 a. 4. Michael Torre, following Gerard Schneemann, S.J., indicates that the distinction between efficacious and sufficient grace was made explicit before the middle of the fifteenth century, as evinced by the work of Henry of the Dominican Gorkum (c.1378-1431). See Michael D. Torre, Do Not Resist the Spirit's Call: Francisco Marin-Sola On Sufficient Grace (Washington, DC: cuA Press, 2013), 285 . 
this view, God, the giver of esse, is the first cause of every positive reality. When the reality in question is the activation of a created agent's capacity for operation, God no less than the created agent is a cause, for there must be an ultimate principle of the created agent's transition from potency to act: nothing moves unless moved by another, and ultimately, by the prime mover, who is God. But what exactly is God's motion of a created cause to act?

While there does not appear to have always been complete uniformity in the answer to this question especially in and prior to the earliest stages of the controversy de auxiliis, the controversy forced clarification of the issue and widespread consensus was achieved under the pressure imposed by the Jesuits. According to this view, now solidified and carried forward by later Thomist commentators, God's motion of a created person to the act of free choice is neither the Divine Act which is God himself, nor the secondary cause itself (here, the human agent), nor the act of the secondary cause (here, the human person's freely choosing). God's premotion of the secondary cause is, rather, a created reality because it is distinct from God. ${ }^{40}$ However, while the premotion is a created reality of a sort, it is not a "creature" in the ordinary sense, insofar as its mode of being is transient rather than subsistent. The premotion is a flowing current of God's efficient causality, an "active force," an "impulse" or "influx" of God's causal agency, linking God, the first cause, to his effect, which, here, is the free operation of the secondary cause. ${ }^{41}$ Premotion is the "ultimate compliment of first act," a kind of medium between first and second act by which God reduces the created cause from potency to act. ${ }^{42}$ In this regard, the premotion intervenes not only between the created cause's first act and second act, but also between God and the secondary cause (and between God and the secondary cause's operation). Nevertheless, the Dominicans understood God's action in the secondary cause to be in a certain sense immediate because nothing intervenes between God's action and the secondary cause or the secondary cause's operation. Moreover, no created cause intervenes between God and the secondary cause or the secondary cause's operation, because premotion is not understood to be a created cause, but rather God's causality (even if, stricto sensu, the premotion is created).

The controversy centered on God's action as an efficient cause, even while both the Dominicans and the Jesuits also believed that God as a final cause moves created causes to act. ${ }^{43}$ Premotion was sometimes described as

\footnotetext{
40 See Álvarez, III d. 19 §§4, 8-9 (149a, 152b-153a, 155a-b); d. 23 §13 (213a-b), §27 (222a).

41 See Álvarez, III d. 18 §9 (136a); and Báñez, Tractatus, II c. 1 \$5 (378); c. 4 §7(407).

42 See for example, Álvarez, III d. 19 §9 (154b-155b); see also d. 23 §27 (222a).

43 A final cause is the purpose of an action or the end seeking to be achieved.
} 
"physical," in order to signify that it was an influx of God's efficient causality, rather than his attractive influence as a final cause. The use of this nomenclature must be understood in context, for "physical" is not here used in the modern sense to signify a collision between bodies, a literal push or shove. Keeping in view the classical sense of physis in one way clarifies and in one way risks obscuring the Dominican point of view. In the classical sense, physis means "nature." According to the Dominicans, God's premotion is antecedent to the operation of the creature in the order of nature and not merely concomitant with it, as on the Jesuit doctrine of concurrence. This is important because it safeguards the natural dependence in acting of secondary causes on the universal first cause. ${ }^{44}$ However, while God's premotion is "natural," his premotion of a created cause is not reducible to his creation and conservation of the secondary cause's nature, with its potencies for operation. God operates in all operating creatures not only by creating and conserving their natures, but also by reducing to act the potencies of the natures he creates and conserves. ${ }^{45}$

One important difference between the Dominican and Jesuit views of divine causality is that for the Dominicans, God's premotion of the secondary cause is his immediate action on - or better, within — the secondary cause, and not only with the secondary cause and on the secondary cause's effect, as the Jesuits maintained with their theory of concurrence. While the Dominicans did not deny that the effects creatures bring about are also immediately related to God as cause, their point was that the dependence of these effects on their respective created causes was itself something that God brings about. For the Dominicans, God's operation within the secondary cause enables the secondary cause to bring about an effect that is properly its own. The created cause remains a cause in its own right, even under (and indeed, because of) God's primary causal influence. The Dominicans understood Thomas's severe criticism of the occasionalistic view of the Islamic Mutakallimun, and they were careful to maintain that God's premotion did not replace the created cause's own action, but instead made the created cause's operation possible. The causal integrity of created agents is one reason why the distinction, elaborated above, of physical premotion from the created cause's own act is extremely important. The created cause's action is dependent upon the action of God, and

44 While the operation of the first universal cause precedes the operation of the secondary cause in the order of nature, this does not imply that God's action is prior in time to the action of the creature. According to the Dominicans, God's action and the creature's action are, in the context of this discussion, temporally simultaneous.

45 Contrast this with the "conservationism" of renegade Dominican, William Durandus. See Alfred Freddoso, "God's Concurrence with Secondary Causes: Why Conservation Is Not Enough," Philosophical Perspectives 5 (1991): 553-85. 
therefore must not be conflated with it, or else secondary causality would be eradicated.

\subsection{Human Freedom}

The immediacy and distinct ontological status of premotion, detailed above, are important for explaining how premotion can be determinative of the action of the secondary cause without destroying the contingency or even freedom of the secondary cause's action. Insofar as the secondary cause's action in its entire positive reality depends upon God in order to be, God's premotion encompasses the very determination, the very specificity of the secondary cause's action. For the specific determination of the secondary cause's action is something actual - it is a positive feature whose origin must be traced back to the prime mover. For this reason, the Dominicans maintained that God's premotion was determinative of the action of the secondary cause and referred to premotion as "predetermination." However, the Dominicans believed that God's predetermination of secondary causes' operations still allowed in principle for those operations to be contingent (including free), because God, as the transcendent creator, is the cause of both the contingent and the necessary and no created cause intervened between God's action and the creaturely potency actualized by him.

Rather than seeing divine predetermination as a threat to human freedom, the Dominicans saw God's predetermination of a human act of choice as the very basis of its freedom. This is because without God's predetermination, the human capacity of free choice remains in potency to the pursuit of a multiplicity of different ends and it is the divine predetermination that reduces the human free-choice capacity from this potency to the actual pursuit of some one determinate object of choice. There is no free act without the motion of the first mover.

Central to the Dominicans' account of creaturely freedom is their appeal to the distinction between the "composed" and "divided" senses of a conditional proposition. To interpret a conditional proposition in the composed sense is to interpret the proposition de dicto or as a whole, taking both the antecedent and the consequent together. To interpret a conditional proposition in the divided sense is to interpret the consequent $d e$ re - that is, in itself, independently from the antecedent. This distinction of the composed and divided affects the truth value of claims about necessity, for while it may be false that some state of affairs picked out by the consequent part of the conditional proposition is necessary (so-called "necessity of the consequent"), it may be true that there is a kind of necessity to the relationship between antecedent and consequent, taking the proposition as a whole (so-called "necessity of the 
consequence"). Here, necessity characterizes not the state of affairs picked out by the consequent, considered de re (on its own), but the logical relationship between the two parts of the dictum, or compound proposition.

Dominicans appealed to the distinction of the composed and divided senses to delimit the indifference required for free choice. Like their Jesuit opponents, the Dominicans understood free choice as the will's indifference to alternative possibilities (both of specification and exercise) in the presence of antecedent conditions. However, unlike their more voluntaristic opponents, the Dominicans considered the intellect (and not the will) to be the principle of free choice, because they held that the will's indifference originates from the intellect's ability to conceptualize different alternatives for choice. For the Dominicans, freedom was radically in the intellect and formally in the will. ${ }^{46} \mathrm{Cru}-$ cially, the Dominicans differed from the Jesuits in their denial that free choice requires the ability to do otherwise in the presence of all antecedents to choice. The Dominicans maintained that while free choice requires the ability to act or not act, to do one thing or another in abstraction from God's premotion (that is, in the divided sense, or de re) - they maintained that free choice does not require indifference on the supposition of God's premotion (that is, in the composed sense, or, de dicto). Given the premotion of Jane to $A$, for example, Jane is not indifferent to $A$-ing. But this premotion does not take away Jane's freedom because Jane still remains the kind of agent who could not- $A$. By nature and in abstraction from God's premotion to $A$, Jane is indifferently disposed toward a variety of ends. Her nature does not determine her to only one thing. Moreover, being indifferently disposed by nature to a variety of ends, Jane stands in potency to the actual pursuit of one of them and she depends upon God's premotion in order to go from being merely able to pursue alternative possibilities to actually pursuing a specific one of them. Therefore, the Dominicans maintain that Jane $A$-s freely when premoved by God to do so, even thought Jane cannot actually $A$ apart from God's premotion, and under God's premotion, Jane's $A$-ing is necessary.

\subsection{Grace and Predestination}

Applying within the supernatural domain the principles that it is beyond the capacity of a human person to act apart from the motion of the first mover, and accordingly, that is beyond the capacity of a human person to determine himself or herself differently than he or she has been determined by first mover, the Dominicans defended the intrinsic and infallible efficacy of actual

46 See Báñez, Sch. com. in ST, I q. 83 a. 1 dub. 2, secunda conclusio (376a). 
grace. For the Dominicans, unlike the Jesuits, God's actual grace was not only antecedently and infallibly efficacious, but also intrinsically efficacious. The efficacy of actual grace on the Dominican account was not rooted in the infallibility of divine foreknowledge, but rather was a metaphysical characteristic of the auxilium itself.

Given the intrinsic antecedent efficacy of divine assistance and the witness of Augustine and Aquinas, it is also not surprising that the Dominicans held for predestination ante praevisa merita. The human person has nothing of his or her own, no merits that preexist divine election which, by being divinely foreseen, could condition his or her election. According to the Dominican view, merits are still a prerequisite for heavenly glory; it is just that the merits on which heavenly reward is founded are due to God's eternal free decision-a decision that is unconditioned by foreknowledge of human merits. On this point, the Dominicans were on firmer theological grounds than Molina and Lessius, as the refinement of the Jesuit view into congruism suggests. But while both the Dominicans and the congruists maintained the unconditioned nature of election, the difference between the way the two theories conceived of the efficacy of actual grace reveals an important difference in their understanding of the scope of predestination. For the specific determination of a human person's choices is not something that God pre-ordains on the congruist view, even while predestination envelops a person's free choices as actual. From the congruist perspective, it is more that a person's self-determinations are something God works with in predestining, whereas from the Dominican perspective, those self-determinations are infallibly pre-ordained by God in predestining.

\subsection{The Divine Permission of Evil}

Still, there is a crucial asymmetry, in the Dominican view, between the ways that good and bad human free choices are pre-ordained by God. This is because God is the source of all that positively exists, but evil, as privation, is not a positive reality. It is rather a lack of what ought to be. In the case of a human free choice, the privation which makes the choice to be bad is the choice's lack of rectitude-its declination from the moral law, namely, the truth about the good that ought to be done. Whereas God causes good free choices by determinately premoving the human person to the good, he does not premove the human person to the evil (the lack of rectitude) that makes a bad choice bad. Rather, the deficiency in the act flows from a defect in the human agent. The classic example used to illustrate this is God's moving a man with an injured shin to limping: God moves the man to limp, but the reason the man limps rather than walks is not because God moved the man to limping as such. There 
is no defect in God's motion. Instead, God moves the injured man as if to walking, but the man can only limp under God's motion because of his own injury.

While moral evil is not itself positively caused or predetermined by God, moral evil's reality does still depend on God's causation of the positive reality of the deficient act that ensconces the evil, as well as on his permission of the evil that afflicts that positive reality of the act. For insofar as evil is privation, evil has a parasitic quality and depends for its reality on being hosted within a subject that, insofar as it is, is good. Thus, in the case of a morally evil choice, while God does not premove the will to evil, he does premove the will to the act as act - that is, he determinately causes the "materiality," or positive reality, of the act. Moreover, no defect can occur unless God permits it, for he could prevent this defect. And here is the difficulty: given the intrinsic efficacy of divine assistance, if God does not provide all of the assistance to do what is morally required, the human person ineluctably fails to do what is morally required. This failure is not due simply to the human person's fallenness, but also to his or her creaturliness: the provision and efficacy of divine assistance is not within the purview of the human recipient as a finite being dependent on God.

\subsection{Critique of the Dominican View}

The Dominicans, with Augustine, Aquinas, and the consistent teaching of the church, clearly preserved the divine initiative in salvation. But they generally did so at high expense, as the concluding point of the last section above begins to reveal. For if the provision and efficacy of premotion is outside of the human recipient's purview, and if the human person cannot act apart from this premotion, and if the human recipient's choices are predetermined by God through his premotion, then it seems to exonerate the human person of moral responsibility and it seems to implicate God in sin, despite the qualifications explained in the last section, above. To pinpoint the weakness more precisely, the problem is that something other than the act of choosing settles the human person's choice. The choice is settled by something antecedent and exogenous to the choice itself. ${ }^{47}$

A defender of the Dominican view might take issue with the point that premotion is exogenous, and instead emphasize that God works interiorly by his premotion. Such a person might argue that premotion should not therefore be reckoned an extrinsic factor to one's choosing. But even if God works interiorly, thinkers on both sides of the divide (with few, if any exceptions) agree on the points that make the Dominican view problematic, even if they do not agree

47 The Jesuits charged the Dominicans with Protestant error on this point. However, the Dominicans disavowed Luther's and Calvin's teachings on the bondage of the will and the Magisterium has cleared the Dominicans of this charge (see DS 2564). 
upon whether these points are problematic: namely, that God's premotion is other than God, other than the human person and other than the human person's choice, and that the premotion originates from outside of the human agent and his or her choice, and that it is antecedent to the choice, terminating in the emergence of the choice. Therefore, even if God works interiorly, getting the human person to elicit his or her own interior act of will, on the Dominican view, human choices are determined by a factor distinct from and external to the choice itself. That is exactly what is required by the principle omne quod movetur ab alio movetur, as it was generally understood by the Dominicans.

Neither will it do to appeal to the fact that it is God, who is transcendent, who is doing the predetermining and not a creature. For the antecedent condition that accounts for the choice's being of what it is of and not otherwisethe antecedent factor that would have to be different for the choice to be different-is not God, but the physical premotion. God is simple and unchanging across different created scenarios (or "possible worlds" to loosely apply a familiar, if infelicitous idea). The antecedent to choice that differs "across worlds" is not God, but the created influx of God's efficient, transeunt causalitysomething entitatively distinct from both God and the human free choice.

Neither will it do to appeal to the fact that the human person can do otherwise because he or she is not determined by nature ad unum but remains naturally disposed toward a variety of possible ends. For this is reducible to the claim that the human person is the sort of being that can be predetermined to act in different ways, not that the human person is the sort of being that can determine itself in different ways. It does not establish that one's choices are up to oneself, or that one could act otherwise under a given premotion-a premotion whose provision, efficacy and determination are outside one's purview as an agent. In this way, the theory of premotion collapses moral responsibility into creaturely finitude: it reduces freedom as self-determination to a created agent's dependence on God for being and action. But if God, as the transcendent cause of finite being, causes the necessary and the contingent as such, this reduction is unnecessary and problematic. While there is a relationship between a human person's creaturely limitedness and his or her ability to sin, insofar as finitude is a condition for the possibility of moral failure, creaturely finitude is not itself moral failure. Genuine self-determination and the moral responsibility it entails are necessary for the intelligibility of moral failure.

While the polemics that characterized the de auxiliis debate can misleadingly suggest that the Dominican and Jesuit positions were the only two games in 
town and that these two positions were monolithic in their uniformity, they were not. There were outlying theologians in both orders, and theologians from outside these two orders also weighed in. However, by-and-large, the Dominicans and the Jesuits remained aligned against each other along party lines with remarkable uniformity up until the early twentieth century.

There is a hackneyed portrayal of the controversy as a sterile, intramural debate that expended the efforts of the brightest theologians of the sixteenth and seventeenth centuries on a pointless exercise in hairsplitting, thereby disrupting the peace and unity of the church at a time when it was already bruised and bleeding from the Protestant schism. While this portrayal has some limited basis in reality, the portrayal is misleading insofar as it suggests that the debate was much ado about nothing. In fact, the de auxiliis question continued to haunt the church for centuries - as long as theologians were willing to think about it — and the question was never adequately answered. The Dominicans and Jesuits were fixated upon a substantive issue - a genuine theological mystery at the heart of the Christian faith-one which deserves the kind of sustained reflection and clear formulation that has been given to such mysteries as the Trinity and the Incarnation. It also ignores the fact that the Dominican and Jesuit positions were serious attempts at giving clear and plausible expression to this mystery, attempts that, from both sides, were intended to further the peace and unity of the church while upholding the integrity of the deposit of faith.

In fact, while neither school articulated a position that was ultimately adequate, both sides had insight into certain fundamental truths. The Dominicans were right in their uncompromising defense of the truth that God is the first cause of all that exists, including the free acts of creatures, and that God has the initiative in salvation. The Jesuits were right to insist that the human person has the capacity for genuine self-determination and that this capacity would be undermined if choices were determined by exogenous created antecedents.

But that both sides had genuine insight into the issue does not mean that a via media is tenable. For common suppositions led both sides into an insoluble dilemma. Chief among these was the highly intuitive but mistaken idea that God's efficient causality is literally a force or influx (somewhat like physical energy), a tertium quid bridging between cause and effect. On such an understanding, God is either determining or determined, as Garrigou-Lagrange pointed out: for the Dominicans, God is determining. For the Jesuits, God is determined. ${ }^{48}$

48 See the Epilogue to God, His Existence and His Nature, 2:259-562. 
This extremely tempting conceptual mistake about efficient causality, taken with each side's true grasp of one pole of the mystery, converged with several other human and, broadly-speaking, methodological factors to make the controversy de auxiliis virtually unavoidable. The dispute between the Dominicans and Jesuits was as complicated humanly as it was conceptually, although the sheer conceptual complexity of the debate tends to eclipse its moral, psychological, and spiritual dimensions.

From a methodological standpoint, neither position took a sufficiently dialectical approach to the mystery, in the broad, medieval sense of determining a position in light of back-and-forth consideration of counterarguments, as in the format for settling disputed questions. It is not that the Dominicans and Jesuits did not consider one another's views or even other counterpositions. It is clear from the structure of their writings (which included dubia and so forth, as was customary) that they did. Rather, there was a dispositional shortcoming on the part of the disputants: in general, neither side was sufficiently self-critical to take the respective counterarguments seriously enough to make significant modifications to its own position. While this posture affected both the Dominicans and Jesuits, it seems to have affected the Dominicans more because they were defending an established position that, in its main lines, had been previously held, and one that, in its specific points of detail, had been developing since the fourteenth century. Whereas the Jesuits were advancing a new theory, they were forced to confront counter-positions from the very start.

This led to another complicating factor-the Dominican and Jesuit positions were polemical. They were positions formulated against someone in the heat of controversy. As a result, the two positions do not display the kind of balance that is necessary to do justice to the mystery as a whole. While this factor affected both schools, it was a more characteristic flaw of the Jesuits than the Dominicans, for the Jesuits developed their view in order to address the problem of Luther and Calvin's teachings on the bondage of the will and the soteriology resultant from these teachings. While this problem affected the Dominicans less in respect to the main lines of their theory, it does seem to have driven the development, clarification, and hardening of the more distinctive features of their account by the 1590s. The rise of the Molinist threat caused the Dominicans to double down on their basic position and this caused declination from a more balanced Thomistic view. The outcome was that sound basic principles were run far forward without stopping to look back and check course. This resulted in a pure, logically tight position to be sure, but a distorted one.

A related factor that contributed to the impasse is party loyalty. Members of both Dominican and Jesuit schools were highly committed to the official 
position of their religious order. I do not mean to suggest that these loyalties were irrational or that they made the protagonists' quest for truth disingenuous. If one were to ask a protagonist from either side the reasons for his position, he would surely have said that he held his position primarily because he thought it to be true, not because it was the position of his order. However, a spirit of partisanship undeniably characterized each side's quest for truth, and to an extent that foreclosed avenues for transcending the conceptual limitations of tightly formed but insufficiently dialectical positions that were forged in the heat of controversy. What was necessary was a sharper distinction between the deposit of faith and apostolic Tradition on the one hand, and a scholastic tradition with its received doctrines on the other. The tendency to conflate theological opinion with what is of the faith has for centuries contributed to the intractability of de auxiliis dispute.

In addition to grasping the fundamental truth about one pole of the mystery, protagonists from each side also grasped the truth about what were the principal deficiencies of their opponents' position, despite the fact that they did not overcome the factors which led them to an impasse. This apprehension of each side's respective deficiencies is not an insignificant contribution to a resolution of the debate. With the benefit of hindsight, it is clearer today than it could have been to thinkers in the sixteenth and seventeenth centuries that both of the principal positions advanced in the controversy were erroneous, despite the real but limited traction they gained in accounting for the relationship between God and human action. The mistakes that were made in the controversy are mistakes that are almost impossible to avoid, especially in a fallen world where even holy and bright thinkers contend not only against their creaturely limitations of intellect, but also against the effects of sin. They are the kind of mistakes that are most visible (and therefore most avoidable) in hindsight-once they have been made and their implications seen. The blunders of the controversy, as vexing and painful as they were, could contribute to the conflict's resolution not only conceptually, but also insofar as they might serve as a chastening reminder of how easily minds greater than our own can err in thinking about so difficult a matter as the relationship of God and secondary causes. A resolution of the conflict depends not only on right thinking, but on right ways of thinking, especially intellectual humility and an abandonment of what Newman calls "love of system."

What is needed today is a fresh re-thinking of the controversy that gets beyond the mistaken suppositions and polemics of the original debate, but which draws upon its lessons. I would propose that a reframing of the controversy must begin from a consideration of God's simplicity and creative causality and explain the implications of these doctrines for conceptualizing God's causation of change in the world. 